\title{
Global Imbalances: Should We Use Fundamental Equilibrium Exchange Rates?
}

\author{
Jamel Saadaoui*
}

September 9, 2013

\begin{abstract}
.
The reduction of global imbalances observed during the climax of crisis is incomplete. In this context, currencies realignments are still proposed to ensure global macroeconomic stability. These realignments are based on equilibrium rates derived from equilibrium exchange rate models. Among these models, we have the fundamental equilibrium exchange rate model introduced by Williamson (1994). This approach is often labelled as normative mainly because the equilibrium is not uniquely determined. If the FEER is not related either in the short or in the long to the real exchange rates, we see no clear justification to intervene in foreign exchange markets based on these equilibrium rates. In this case, the FEER does not include any element of long run predictive value and should not be used to reduce global imbalances. This paper provides panel empirical evidences that the FEER is related to real exchange rate in the long run and thus could be a useful tool to prevent the resurgence of large global imbalances and associated risks.
\end{abstract}

JEL Classification: C23, F31, F32, F33, F41.

Key words: Global Imbalances, Equilibrium Exchange Rate, International Monetary Cooperation.

*Associate Professor, Bureau of Economic Theory and Applications, University of Strasbourg, France, saadaoui@unistra.fr. The author is grateful to John Williamson for very valuable remarks and comments. All errors or omissions are mine. 


\section{Introduction}

International trade would cease to be what it is, namely, a desperate expedient to maintain employment at home by forcing sales on foreign markets and restricting purchases, which, if successful, will merely shift the problem of unemployment to the neighbour which is worsted in the struggle. John Maynard Keynes (1936).

As witnessed by the evolution of current account balances and net foreign assets, the reduction of global imbalances observed during the climax of crisis is incomplete. Indeed, current account imbalances in flow have been reduced with the global slowdown and the collapse of the world trade in 2009. However, these evolutions of current account imbalances have not been sufficient to reduce net foreign assets positions in stock. After the climax of the crisis, global imbalances in stock (i.e. the net foreign assets positions) represent more than $15 \%$ of world GDP in absolute value.

As pointed out by Blanchard and Milesi-Ferretti (2012), the persistence of large current account imbalances and large net foreign assets positions is a threat for the world economy. Firstly, large current account imbalances increase the systemic risks as countries with large deficits can be subject to sudden stops and their macroeconomic consequences. Secondly, they increase political tensions as a number of countries, which are suspected of unfair competition with undervalued exchange rates, could be threatened by retaliatory measures. Thirdly, in the current context of weak growth in advanced countries, the perpetuation of export-led growth strategies in some emerging countries could be a menace for the global recovery.

This last point is illustrated in the quotation above, Keynes (1936) emphasizes that the main economies must have mutually consistent objectives in terms of external trade and exchange rate policies in a context of depressed aggregate demand at the world level. If some countries lead aggressive exchange rates policies and restrict their internal demand in order to run current account surpluses, they will induce further downward pressures on the global aggregate demand.

Chinn et al. (2013) claim that current account imbalances of the USA and China will not disappear in absence of radical policy change. Gagnon (2011) forecasts that current account imbalances will widen in larger proportion at the world level than projected by the International Monetary Fund (IMF). Feldstein (2011) argues that exchange rate adjustments (or currency realignments) could play a major role in the elimination of current account imbalances of the USA and China. He stresses that internal policies must be accompanied by external policies to maintain domestic macroeconomic balance. As the current account is equal to the difference between national saving and national investment, deficit countries must increase 
their national saving and/or reduce their national investment. To sustain such a change (maintain aggregate demand and non-inflationary full employment), a real effective depreciation is required in these countries. Surpluses countries must decrease their national saving and/or increase their national investment. To eschew inflationary pressures, a real effective appreciation is required.

In this context, currencies realignments are still proposed to reduce current account imbalances and ensure global macroeconomic stability at the world level. These realignments are based on equilibrium rates derived from equilibrium exchange rate models.

Driver and Westaway (2005) provide an authoritative survey on the different concepts of equilibrium exchange rate in the current literature. Their contribution details under which circumstances a specific approach is likely to be appropriate. They quote 14 different approaches 1 and classify them according to the time horizon concerned by the measure of equilibrium exchange rate. They distinguish three time horizons, namely, the short run, the medium run and the long run. One their main conclusion is that the relative relevance of an approach must be considered in the perspective of the question that the approach tries to tackle.

When the question at hand is the reduction of global imbalances, the potential candidates are the fundamental equilibrium exchange rate (FEER) introduced by Williamson (1994), the behavioral equilibrium exchange rate (BEER) introduced by Clark and MacDonald (1998) and the natural rate of exchange rate (NATREX) introduced by Stein and Allen (1998).

Unlike the purchasing parity power (PPP) introduced by Cassel (1918), these approaches are clearly related to the global imbalances problematic. The FEER approach endeavors to stabilize the current account at a sustainable level in the medium run in order to assure a possible convergence towards the full stock-flow equilibrium in the long run (Driver and Westaway, 2005). Besides, the NATREX approach and recent versions of the BEER approach (López-Villavicencio et al., 2012) aim to stabilize the net foreign assets position in the long run thus they represent the full stock-flow equilibrium in the long run (Driver and Westaway, 2005).

Indeed, López-Villavicencio et al. (2012) show empirically that the FEER converges towards the full stock-flow equilibrium (i.e. the BEER) in the long run. In spite of an impressive endeavor in theoretical modelling, the empirical testing of the NATREX is extremely close to the empirical testing of the BEER in an overwhelming number of cases in the current state of the literature. From an empirical perspective, it is quite difficult to distinguish these two last approaches.

It remains to tow potential candidates to study issues surrounding global imbalances, namely, the FEER and the BEER. In spite of all its advantages, the BEER

\footnotetext{
${ }^{1}$ See Driver and Westaway $(2005)$ for more details.
} 
suffers from two important drawbacks: its time horizon and a strong assumption on the misalignments $2^{2}$. Firstly, the relevant time horizon for the BEER approach is the long run but as underlined by López-Villavicencio et al. (2012), the relevant horizon to treat the global imbalances question is the medium run. Secondly, as in the PPP and in the NATREX, the BEER makes the implicit assumption that the exchange was in equilibrium on average on the studied period (i.e. exchange rate misalignments are stationary by construction) $)^{3}$.

This last assumption could be justified in large panel with the main economies and over a long period of time. But we see no justification to this hypothesis in a single country context or in a regional context over a short period of time. The FEER does not suffer from these two last important limitations. As its relevant time horizon is the medium run and as it makes any assumption on the stationarity of misalignments, the FEER seems to be a natural candidate to study the global imbalances question.

Nevertheless, the FEER suffers from its own limitations. This approach is often labelled as normative mainly because the equilibrium is not uniquely determined. If the FEER is not related either in the short or in the long to the real exchange rates, we see no clear justification to intervene in foreign exchange markets based on these equilibrium rates. In this case, the FEER does not include any element of long run predictive value ${ }^{4}$ and should not be used to reduce global imbalances. This paper provides panel empirical evidences that the FEER is related to real exchange rate in the long run and thus could be a useful tool to prevent the resurgence of large global imbalances and associated risks.

Several studies have examined the relationship between the FEER and the real effective exchange rate (REER). We can quote Zhou (1993), Barisone et al. (2006), Saadaoui (2011) and Duwicquet et al. (2013).

Zhou (1993) finds that FEERs are not cointegrated with REERs (i.e. the misalignments are not stationary) however we can underline an important drawback in her empirical study. She studies only two countries (Germany and Japan) over

\footnotetext{
${ }^{2}$ An exchange rate misalignment is defined as the difference between the observed exchange rate and the equilibrium exchange rate.

${ }^{3}$ In the BEER approach, the exchange rate is regressed against fundamental determinants. The exchange rate misalignments correspond to the difference between the observed values and the fitted values (i.e. the residuals). The residuals are stationary by definition.

${ }^{4}$ We think that our empirical results are a common feature of all FEER approaches. If we test several FEER approaches and find that they are related with observed rates, we can conclude that observed rates return to these array of fundamental rates in reason of real forces (trade evolutions) or public interventions (the Louvre accord, for example). This set of FEERs (REERs that are consistent with continued non-crisis evolution of the economy) have an element of long run predictive value in saying that the exchange rate must follow one of those path and the normative element only arises in choosing which. The author is grateful to John Williamson for conceptual clarifications on this point.
} 
a relatively limited time span (1974-1988). Besides, during this period, it is well known that these two countries have used their exchange rate policy to boost their external competitiveness. Thus, the results of Zhou (1993) are not surprising since global consistency, mentioned above, is not ensured.

Contrary to Zhou (1993), Barisone et al. (2006) find that the FEERs are cointegrated with REERs for the G7 countries over the period 1973 to 1997. They use recent non-stationary panel econometric techniques. This study can be considered as more complete comparatively to Zhou (1993) as the number of countries and the number of observation is larger.

Saadaoui (2011) finds non-stationary panel evidences that the FEERs are cointegrated with REERs for a panel of 17 industrialized and emerging countries over the period 1982 to 2007. This study is the first to include emerging countries in the sample and constitutes an improvement toward a greater global consistency.

In Duwicquet et al. (2013), we can observe that the FEER approach does not require any assumption on the stationarity of the misalignment contrary to other approaches. They study a sample of member of the eurozone over the period 1994 to 2010. As witnessed by the euro crisis, European economies have experienced diverging paths in terms of competitiveness. Thus, these evolutions imply that the misalignments have been non-stationary over the period. This last study and that of Zhou (1993) show that the FEER is more flexible than other approaches.

Comparatively to these studies, this empirical investigation improves several points. We use recent non-stationary panel econometric techniques to investigate if the FEER is related to the REER for a large panel of 26 industrialized and emerging countries over the period 1982 to 2010. We find a positive long run relationship between FEER and REER, confirming the validity of the use of FEER as instrument to correct currency misalignment and reduce in this way current account imbalances among the main areas of the world.

This paper is organized as follow. Section 2 presents a general framework suited to describe every FEER approach. Section 3 focusses on empirical evidences for a large panel of 26 industrialized and emerging countries 5 over the period 1982 to 2010. Section 4 concludes on the usefulness of the FEER approach to reduce global imbalances.

\section{FEER Methodology}

In the literature on equilibrium exchange rates, the FEER approach has several variants. We can quote Cline (2008), Jeong et al. (2010), You and Sarantis (2011) and Carton and Hervé (2012) for example. These variants differs on the type

\footnotetext{
${ }^{5}$ Country list is given in appendix $\mathrm{A}$
} 
and size of modelling (general equilibrium, partial equilibrium, reduced form relationship), on the determination of the sustainable current account in the medium term (econometric estimates, judgmental assessment, arithmetic average) and on the trade elasticities (calibration to balance the trade model in volume and value, econometric estimates in a panel setting to ensure consistency of the world trade model).

In spite of all these differences, we present a general framework adapted to describe every FEER approach. We start with a simple current account model based on Clark and MacDonald (1998):

$$
\begin{gathered}
C A=-K A \\
C A=n t b+n f a r \\
n t b=b_{0}+b_{1} q+b_{2} y d p o t+b_{3} y f p o t \\
n f a r=f(q)
\end{gathered}
$$

Where $C A$ is the current account balance, $K A$ is the capital account, $n t b$ is the net trade balance, $n$ far represents returns of net foreign assets, $q$ is the real effective exchange rate (when $q$ increases, we observe a real effective depreciation), $y d p o t$ is the domestic full employment output and $y$ fpot represents full employments output of foreign economies.

A real effective depreciation and an increase of full employments output of foreign economies improve the net trade balance $\left(b_{1}>0, b_{3}>0\right)$, an increase of the domestic full employment output deteriorates the net trade balance $\left(b_{2}<0\right)$. Combining equations (1) to (4) gives:

$$
C A^{*}=f\left(q^{\text {reer }}, \text { ydpot, yfpot }\right)=-K A^{*}
$$

Where $C A^{*}$ is the sustainable current account in the medium term. To determine the FEER, every approach has to solve the following equation:

$$
q^{f e e r}=f\left(K A^{*}, y d p o t, y f p o t\right)
$$

We obtain the fundamental equilibrium exchange rate $\left(q^{\text {feer }}\right)$, which realizes simultaneously the external and internal equilibrium for all trading partners.

In our approach, we use a two-step procedure to obtain the fundamental equilibrium exchange rate for each trading partners (Jeong et al., 2010). Firstly, we use a partial equilibrium model of world trade for the main countries at the world level (US, China, Japan, Euro area, UK and the Rest of the World). We solve 
equation (6) to obtain fundamental equilibrium exchange rates for these countries in a partial equilibrium model of 35 equations. Secondly, we use simple national model in which world demand and world price are exogenous for smaller economies. National estimates are linked with the estimates of the main countries at the world leve $]^{6}$. In that case the misalignments (i.e. the difference between observed rates and equilibrium rates), written in differential logarithmic $\left(r=d \log R=\left(R i-R^{e}\right) / R^{e}\right)$, are computed as 7 .

$$
r=\frac{1}{s x} \cdot\left[\frac{b}{m x}+\eta m \cdot d i-\eta x \cdot d^{*}\right]
$$

Where $b$ is the difference between the observed current account and the equilibrium one, as percentage of GDP, $d$ and $d^{*}$ stand for internal and world demand in volume, also written in differential logarithmic, $\eta m$ and $\eta x$ are import and export volume elasticities, $s x$ and $m x$ are coefficients derived from the foreign trade model in which mark-up behaviours are allowed.

Concerning the determination of the sustainable current account in the medium term, following (Chinn and Prasad, 2003), we regress the current account on several medium-term determinants of investment and saving behaviours. The consistency of current account targets is ensured by using the Rest of the World as a residual. At the world level, the sum of current account targets expressed in the same currency is equal to zero.

The trade elasticities of the world trade model come from econometric estimates. These estimates are generally made in a panel setting to ensure that elasticities are mutually consistent 8 .

Although, there are several variants of the FEER approach in the literature on equilibrium exchange rates, this simplified framework contains the essential principles which are included in all FEER approaches.

Two other important points can be mentioned: firstly, on exchange rate dynamics, and secondly, on uncertainties surrounding estimates of equilibrium ex-

\footnotetext{
${ }^{6}$ Notice that the FEER estimates are not obtained country-by-country but in a consistent framework by relying on a world trade model for the main economic areas.

${ }^{7} R^{e}$ is the equilibrium exchange rate. Our FEER model includes only three exogenous variables, namely, the current account gap (difference between the observed current account balance and the equilibrium current account balance), the internal demand gap (difference between the observed internal demand and equilibrium internal demand) and the world demand gap (difference between the observed world demand and equilibrium world demand). The real effective exchange rate is not included as an endogenous variable of the model. In a first step, we solve the model in differential logarithmic to obtain misalignments. In a second step, we retrieve the FEER by using this formula: $R^{e}=\exp ^{(\log R)-r}$ where $R$ is the real effective exchange rate and $r$ is the real effective misalignment.

${ }^{8}$ See Jeong et al. (2010) for more details and a complete description of the model and methodology.
} 
change rates. It seems clear that the FEER model does not describe exchange rate dynamics nevertheless it appears reasonable to think that an increasing current account deficit (surplus), a persistent negative (positive) domestic output gap and a growing positive (negative) foreign output gap will induce downward (upward) pressures on the exchange rate. Concerning uncertainties surrounding estimates of equilibrium exchange rates ${ }^{9}$ Ca' Zorzi et al. (2012) investigate if current account balances of the main economies were in line with fundamentals before the financial crisis. To take into account uncertainty, they used Bayesian panel econometric techniques. According to their results, current account deficits of the United States and of the United Kingdom were excessive before the financial crisis. Besides, current account surpluses of Japan and China were excessive in regards to their fundamentals. They conclude that it is highly unlikely that current account balances of the main economies were in line with fundamentals prior to the financial crisis.

This last result may imply that exchange rates were not in line with their fundamentals before the financial crisis. Thus our empirical investigation can be considered as a worthwhile attempt to check if exchange rates will return to their fundamental values, namely, their FEER values, after the financial crisis and in this way realign current account balances of the main economies to their fundamental long run values.

\section{Empirical Results}

The purpose of this section is threefold. Firstly, we estimate FEERs for 26 industrialized and emerging countries over the period 1982 to 2010 with the methodology described above ${ }^{10}$. Secondly, we run some regressions on the series of FEERs and REERs to determine if we are in a non-stationary panel context. Thirdly, we use non-stationary panel econometric techniques which allows for cross-section dependencies and heterogeneous slopes to test empirically the usefulness of the FEER approach to correct exchange rate misalignment and in this way reduce global imbalances and associated risks.

As we can observe in figure 1, there is a clear positive correlation between real effective exchange rates and fundamental equilibrium exchange rates. However, as correlation does not imply any causal structure, we study a bi-directional causal relationship between FEERs and REERs with static and dynamic OLS regressions.

\footnotetext{
${ }^{9}$ Uncertainties surrounding equilibrium exchange rates are widely documented. Cheung et al. (2009), Dunaway et al. (2009) and Schnatz (2011) examine uncertainties surrounding the equilibrium exchange rate of China in several models (the PPP, the BEER and the FEER, respectively).

${ }^{10}$ Misalignments, real effective exchange rates and fundamental equilibrium exchange rates are presented in appendix $\mathrm{B}$
} 
Figure 1: Linear correlation between REERs and FEERs



Source: author's calculation for fundamental equilibrium exchange rates and BIS, IFS, Bruegel for real effective exchange rates $(2000=100$, log scale). 
We can observe in static OLS estimates (columns (1) and (2) in table 1) that there is first-order autocorrelation in the residual series. Besides, the value of the R-squared statistic is substantially higher than the value of the Durbin-Watson statistic. We may suspect the presence of fallacious regressions (Granger and Newbold, 1974). When we use dynamic OLS estimates (columns (3) and (4) in table 1), first-order autocorrelation in the residual series is corrected and coefficients are positive and significant as expected however they give no information on the long run relationship between REERs and FEERs. Kao and Chiang (2000) show that the OLS estimator is convergent but not efficient in a cointegrated panel.

Table 1: Static and Dynamic OLS estimates

\begin{tabular}{|c|c|c|c|c|}
\hline OLS & $\begin{array}{l}(1) \\
\text { logreer }\end{array}$ & $\begin{array}{l}(2) \\
\text { logfeer }\end{array}$ & $\begin{array}{l}(3) \\
d(\text { logreer })\end{array}$ & $\begin{array}{l}(4) \\
d(\text { logfeer })\end{array}$ \\
\hline Constant & $\begin{array}{l}1.394 * * * \\
(0.000)\end{array}$ & $\begin{array}{l}0.895 * * * \\
(0.000)\end{array}$ & $\begin{array}{l}0.004 \\
(0.242)\end{array}$ & $\begin{array}{l}0.003 \\
(0.501)\end{array}$ \\
\hline $\mathrm{d}($ logreer $)$ & & & & $\begin{array}{l}0.552 * * * \\
(0.000)\end{array}$ \\
\hline$d($ logfeer $)$ & & & $\begin{array}{l}0.328 * * * \\
(0.000)\end{array}$ & \\
\hline logreer & & $\begin{array}{l}0.807 * * * \\
(0.000)\end{array}$ & & \\
\hline logfeer & $\begin{array}{l}0.694 * * * \\
(0.000)\end{array}$ & & & \\
\hline Observations & 754 & 754 & 728 & 728 \\
\hline R-squared & 0.559 & 0.559 & 0.181 & 0.181 \\
\hline DW-statistic & 0.416 & 0.498 & 1.763 & 2.051 \\
\hline
\end{tabular}

Results in table 2 may induce that our panel is cointegrated since OLS estimates of cointegrating vector are very similar to DOLS estimates in terms of convergence Kao and Chiang, 2000).

To determine in a more formal way if we are in non-stationary panel context, we need to implement the following steps. Firstly, we apply several panel unit root tests on the series of real effective exchange rates and on the series on fundamental equilibrium exchange rates. Secondly, if the series are nonstationary I(1) series, we apply several panel unit root test to determine if real effective exchange rates and fundamental equilibrium exchange rates are cointegrated. Thirdly, if the series are cointegrated, we estimates several panel error correction model which control 
for cross-section dependencies and heterogeneous slopes in order to conclude on usefulness of the FEER to correct misalignments and in this way reduce current account imbalances among the main area in the world.

Table 2: Dynamic OLS estimates

\begin{tabular}{llll}
\hline Kao and Chiang & $(1)$ & & $(2)$ \\
DOLS & logreer & & logfeer \\
\hline logfeer & $\mathbf{0 . 6 7 7 * * *}$ & logreer & $\mathbf{0 . 8 2 0 * * *}$ \\
& $\mathbf{( 0 . 0 0 0 )}$ & & $\mathbf{( 0 . 0 0 0 )}$ \\
Observations & 624 & Observations & 624 \\
R-squared & 0.431 & R-squared & 0.436 \\
\hline
\end{tabular}

Notes: p-values in parentheses. The number of differenced lags / leads used is equal to 2 .

Source: author's calculations.

Table 3: Panel unit root tests

\begin{tabular}{lll}
\hline Breitung and Das (2005) & Level & First Difference \\
\hline \hline logfeer & -0.626 & $\mathbf{- 4 . 6 4 4}$ \\
& $(0.265)$ & $\mathbf{( 0 . 0 0 0 )}$ \\
logreer & 0.559 & $\mathbf{- 4 . 2 6 6}$ \\
& $(0.711)$ & $\mathbf{( 0 . 0 0 0 )}$ \\
Observations & 754 & 728 \\
\hline Pesaran (2007) & Level & First Difference \\
\hline \hline logfeer & -1.274 & $\mathbf{- 6 . 4 8 8}$ \\
logreer & $(0.101)$ & $\mathbf{( 0 . 0 0 0 )}$ \\
& 0.169 & $\mathbf{- 5 . 3 3 6}$ \\
Observations & $(0.567)$ & $\mathbf{( 0 . 0 0 1 )}$ \\
\hline
\end{tabular}

Notes: p-values in parentheses. Statistics are robust to cross-sectional correlation.

Source: author's calculations.

In table 3, panel unit root tests introduced by Breitung and Das (2005) and Pesaran (2007) indicate that series are nonstationary I(1) series as an I(1) series achieves stationarity after first differencing. Our next step will consist in testing panel cointegration. 
Table 4: Panel cointegration tests

\begin{tabular}{|c|c|c|}
\hline Pedroni $(1999)$ & logreer, logfeer & \\
\hline Panel-v & 0.532 & $(0.297)$ \\
\hline Panel-rho & -2.659 & $(0.003)$ \\
\hline Panel-PP & -3.790 & $(0.000)$ \\
\hline Panel-ADF & -6.917 & $(0.000)$ \\
\hline Group rho-Statistic & -0.691 & $(0.244)$ \\
\hline Group PP-Statistic & -3.218 & $(0.000)$ \\
\hline Group ADF-Statistic & -5.706 & $(0.000)$ \\
\hline Pedroni (1999) & logfeer, logreer & \\
\hline Panel-v & 0.967 & $(0.166)$ \\
\hline Panel-rho & -4.488 & $(0.000)$ \\
\hline Panel-PP & -5.399 & $(0.000)$ \\
\hline Panel-ADF & -4.232 & $(0.000)$ \\
\hline Group rho-Statistic & -2.221 & $(0.013)$ \\
\hline Group PP-Statistic & -4.724 & $(0.000)$ \\
\hline Group ADF-Statistic & -4.338 & $(0.000)$ \\
\hline Included observations & 754 & \\
\hline
\end{tabular}

Note: p-values in parentheses.

Source: author's calculations. 
To test cointegration, we use the panel and group statistics introduced by Pedroni (1999) and the panel and the "mean group" statistics suggested by Westerlund (2007). The existence of negative error-correction term is taken as proof for cointegration in these last tests. To take into account cross-sectional dependence, critical values are obtained through bootstrapping. As we can see in Table 4 and 5 , an overwhelming majority of tests indicates that variables are cointegrated. Our next steps will consist in estimating several panel error correction model which control for cross-section dependencies and heterogeneous slopes to conclude on the long run relationship between FEERs and REERs.

Table 5: Panel cointegration tests

\begin{tabular}{llll}
\hline Westerlund (2007) & logfeer, logreer & Z-value & Robust P-value \\
\hline \hline$G \tau$ & -2.328 & -6.627 & 0.000 \\
$G \alpha$ & -7.455 & -4.095 & 0.000 \\
$P \tau$ & -10.104 & -6.427 & 0.000 \\
$P \alpha$ & -5.323 & -7.566 & 0.010 \\
\hline Westerlund (2007) & logreer, logfeer & Z-value & Robust P-value \\
\hline \hline$G \tau$ & -1.661 & -3.355 & $\mathbf{0 . 0 1 0}$ \\
$G \alpha$ & -4.714 & -1.022 & $\mathbf{0 . 0 8 0}$ \\
$P \tau$ & -8.020 & -4.641 & $\mathbf{0 . 0 2 0}$ \\
$P \alpha$ & -3.495 & -4.347 & $\mathbf{0 . 0 3 0}$ \\
\hline
\end{tabular}

Notes: p-values for cointegration tests are based on bootstrap methods, where 100 replications are used. See Persyn and Westerlund (2008) for the details.

Source: author's calculations.

In table 6, we report estimates of a panel error correction model with heterogeneous slopes. We use the Pooled Mean Group (PMG) methodology introduced by Pesaran et al. (1999). As we can note the error correction terms are negative and significant in all specifications thus the error correction representations are validated. The Hausman test allows discriminating among different levels of heterogeneity. Under the null hypothesis of this test, the PMG estimator is efficient. Thus, we can observe positive bidirectional causality between FEERs and REERs in PMG estimates.

In order to check the robustness of the results to cross-sectional dependence, we use a cross-sectionally augmented Pooled Mean Group (CPMG) following Binder and Offermanns (2007). In this approach, we augment the PMG estimator (Pesaran et al., 1999) with cross sectional average of independent and dependent 
Table 6: Panel error correction model with heterogeneous slopes

\begin{tabular}{|c|c|c|c|c|c|}
\hline $\begin{array}{l}\text { Pesaran et al. 1999) } \\
\text { MG }\end{array}$ & $\begin{array}{l}(1) \\
\text { D.logreer }\end{array}$ & $\begin{array}{l}(2) \\
\mathrm{SR}\end{array}$ & MG & $\begin{array}{l}\text { (3) } \\
\text { D.logfeer }\end{array}$ & $\begin{array}{l}(4) \\
S R\end{array}$ \\
\hline EC & & $\begin{array}{l}-0.247 * * * \\
(0.000)\end{array}$ & $\mathrm{EC}$ & & $\begin{array}{l}-0.380 * * * \\
(0.000)\end{array}$ \\
\hline D.logfeer & & $\begin{array}{l}0.210 * * * \\
(0.000)\end{array}$ & D.logreer & & $\begin{array}{l}0.376 * * * \\
(0.003)\end{array}$ \\
\hline logfeer & $\begin{array}{l}0.279 \\
(0.271)\end{array}$ & & logreer & $\begin{array}{l}0.675 * * \\
(0.027)\end{array}$ & \\
\hline Constant & & $\begin{array}{l}0.378 * * \\
(0.011)\end{array}$ & Constant & & $\begin{array}{l}0.691 * * \\
(0.024)\end{array}$ \\
\hline PMG & D.logreer & $\mathrm{SR}$ & PMG & D.logfeer & SR \\
\hline EC & & $\begin{array}{l}-0.199 * * * \\
(0.000)\end{array}$ & EC & & $\begin{array}{l}-0.327 * * * \\
(0.000)\end{array}$ \\
\hline D.logfeer & & $\begin{array}{l}0.222 * * * \\
(0.000)\end{array}$ & D. logreer & & $\begin{array}{l}0.363 * * * \\
(0.001)\end{array}$ \\
\hline logfeer & $\begin{array}{l}0.643 * * * \\
(0.000)\end{array}$ & & logreer & $\begin{array}{l}0.708 * * * \\
(0.000)\end{array}$ & \\
\hline Constant & & $\begin{array}{l}0.330 * * * \\
(0.000)\end{array}$ & Constant & & $\begin{array}{l}0.444 * * * \\
(0.000)\end{array}$ \\
\hline Hausman test & $\begin{array}{l}1.840 \\
(0.174)\end{array}$ & & Hausman test & $\begin{array}{l}0.010 \\
(0.922)\end{array}$ & \\
\hline Observations & & 728 & Observations & & 728 \\
\hline
\end{tabular}

Notes: $\mathrm{p}$-values are given in parentheses. $\mathrm{D}$ is the difference operator, EC corresponds to the error correction term and SR stands for the dynamic part of the error correction model. The null hypothesis in the Hausman test is homogeneity of the long run coefficient in the PMG estimation.

Source: author's calculations. 
variables in order to capture the common factors or the heterogeneous time effect:11.

The results are presented in tables 7 are largely similar to those of table 6 . The estimations give clear cut results. They clearly show a positive and significant bidirectional long-run relationship between real effective exchange rates and fundamental equilibrium exchange rates in panel error correction model with heterogeneous slopes and cross-sectional dependence ${ }^{12}$.

In case of cyclical evolution of competitiveness, the half-life ${ }^{13}$ is equal to 3.909 years. For structural evolution of competitiveness, the half-life is equal to 2.510 years. When a country experienced a cyclical evolution of its competitiveness, he can slow the return to equilibrium in case of unfavourable evolutions hence a longer half-life ${ }^{14}$.

As we have some evidences that there is a positive long run bidirectional between FEERs and REERs, a last robustness check will consist to use two nonstationary panel estimators which allows for cross-sectional dependence in the long run relationship, namely, the Common Correlated Effects Mean Group (CCEMG) estimator developed in Pesaran (2006) ${ }^{15}$ and the DOLS estimator with heterogeneous time trend, common time effect introduced in Mark and Sul (2003). Results in table 8 and 9 confirm previous results however the cointegrating vectors are somewhat different but remain positive and statistically significant.

We provide robust empirical evidences that FEERs are related in the long run with observed rates even if exchange rate dynamics is not explicitly described in the model. These results confirm the usefulness of FEER to correct currency misalignments and reduce in this way global imbalances and associated risks.

\section{Conclusion}

The reduction of global imbalances observed during the climax of crisis is incomplete as witnessed by the evolution of net foreign assets positions. After the climax of the crisis, global imbalances in stock (i.e. the net foreign assets positions) represent more than $15 \%$ of world GDP in absolute value. In this context, currencies

\footnotetext{
${ }^{11}$ See appendix $\mathrm{C}$ for more details.

${ }^{12}$ Results of the heterogeneous dynamic part of the error correction model are presented in appendix D

${ }^{13}$ The half-lives are computed by using the following formula: $h=-\ln (0.5) / \ln (1+|\phi|)$. They correspond to the number of periods for a deviation (from the long run equilibrium) to decay by $50 \%$. Here, deviations correspond to misalignments.

${ }^{14}$ See Saadaoui (2011) for a distinction between cyclical and structural evolutions of competitiveness.

15 Kapetanios et al. (2011) prove that CCE estimators keep consistency when variables are non-stationary.
} 
Table 7: Panel error correction model with heterogeneous slopes and cross-sectional dependence

\begin{tabular}{|c|c|c|c|c|c|}
\hline $\begin{array}{l}\text { Binder and Offermanns 2007) } \\
\text { CMG }\end{array}$ & $\begin{array}{l}\text { (1) } \\
\text { D.logreer }\end{array}$ & $\begin{array}{l}(2) \\
\text { SR }\end{array}$ & CMG & $\begin{array}{l}\text { (3) } \\
\text { D.logfeer }\end{array}$ & $\begin{array}{l}(4) \\
\text { SR }\end{array}$ \\
\hline EC & & $\begin{array}{l}-0.385^{* * *} \\
(0.000)\end{array}$ & EC & & $\begin{array}{l}-0.445 * * * \\
(0.000)\end{array}$ \\
\hline D.logfeer & & $\begin{array}{l}0.150 * * * \\
(0.001)\end{array}$ & D.logreer & & $\begin{array}{l}0.258 * * \\
(0.028)\end{array}$ \\
\hline D.logreer_cs & & $\begin{array}{l}0.645 * * \\
(0.011)\end{array}$ & D.logfeer_cs & & $\begin{array}{l}0.889 * * * \\
(0.000)\end{array}$ \\
\hline D.logfeer_cs & & $\begin{array}{l}-0.178 \\
(0.168)\end{array}$ & D.logreer_cs & & $\begin{array}{l}-0.203 \\
(0.398)\end{array}$ \\
\hline logfeer & $\begin{array}{l}0.365 \\
(0.224)\end{array}$ & & logreer & $\begin{array}{l}3.197 \\
(0.133)\end{array}$ & \\
\hline L.logreer_cs & $\begin{array}{l}3.051 \\
(0.100)\end{array}$ & & L.logfeer_cs & $\begin{array}{l}-0.858 \\
(0.681)\end{array}$ & \\
\hline logfeer_cs & $\begin{array}{l}-1.094 \\
(0.234)\end{array}$ & & logreer_cs & $\begin{array}{l}-7.578 \\
(0.249)\end{array}$ & \\
\hline Constant & & $\begin{array}{l}-0.397 \\
(0.556)\end{array}$ & Constant & & $\begin{array}{l}-0.086 \\
(0.927)\end{array}$ \\
\hline CPMG & D.logreer & SR & CPMG & D.logfeer & SR \\
\hline EC & & $\begin{array}{l}-0.194 * * * \\
(0.000)\end{array}$ & EC & & $\begin{array}{l}-0.318 * * * \\
(0.000)\end{array}$ \\
\hline D.logfeer & & $\begin{array}{l}0.215 * * * \\
(0.000)\end{array}$ & D.logreer & & $\begin{array}{l}0.399 * * * \\
(0.002)\end{array}$ \\
\hline D.logreer_cs & & $\begin{array}{l}0.621 * * * \\
(0.007)\end{array}$ & D.logfeer_cs & & $\begin{array}{l}0.835 * * * \\
(0.000)\end{array}$ \\
\hline D.logfeer_cs & & $\begin{array}{l}-0.228^{*} \\
(0.092)\end{array}$ & D.logreer_cs & & $\begin{array}{l}-0.388^{*} \\
(0.066)\end{array}$ \\
\hline logfeer & $\begin{array}{l}0.738 * * * \\
(0.000)\end{array}$ & & logreer & $\begin{array}{l}0.698 * * * \\
(0.000)\end{array}$ & \\
\hline L.logreer_cs & $\begin{array}{l}-0.028 \\
(0.860)\end{array}$ & & L.logfeer_cs & $\begin{array}{l}0.426 * * * \\
(0.000)\end{array}$ & \\
\hline logfeer_cs & $\begin{array}{l}-0.187 \\
(0.109)\end{array}$ & & logreer_cs & $\begin{array}{l}-0.649 * * * \\
(0.000)\end{array}$ & \\
\hline Constant & & $\begin{array}{l}0.429 * * * \\
(0.000)\end{array}$ & Constant & & $\begin{array}{l}0.772 * * * \\
(0.000)\end{array}$ \\
\hline Hausman test & $\begin{array}{l}2.710 \\
(0.438)\end{array}$ & & & $\begin{array}{l}2.250 \\
(0.521)\end{array}$ & \\
\hline Observations & & 728 & Observations & & 728 \\
\hline
\end{tabular}

Notes: $p$-values are given in parentheses. $\mathrm{D}$ is the difference operator, $\mathrm{L}$ is the lag operator, $\mathrm{EC}$ corresponds to the error correction term and SR stands for the dynamic part of the error correction model. Variables with the suffix "_cs" correspond to cross-sectional average of the variables. The null hypothesis in the Hausman test is homogeneity of the long run coefficient in the CPMG estimation.

Source: author's calculations. 
Table 8: FEER / REER long run relationship

\begin{tabular}{llll}
\hline Pesaran & $(2006)$ & CCEMG & $(2)$ \\
CCEMG & logreer & logreer & $\begin{array}{l}\mathbf{0 . 6 6 4 * * *} \\
\text { logfeer }\end{array}$ \\
\hline logfeer & $\mathbf{0 . 4 2 5 * * *}$ & $\mathbf{0 . 0 0 0 )}$ \\
& $\mathbf{( 0 . 0 0 0 )}$ & logfeer_cs & 0.304 \\
logreer_cs & 0.310 & & $(0.137)$ \\
& $(0.211)$ & logreer_cs & -0.351 \\
logfeer_cs & -0.202 & & $(0.251)$ \\
& $(0.485)$ & Constant & 0.831 \\
Constant & 0.033 & & $(0.310)$ \\
Observations & $(0.976)$ & Observations & 754 \\
\hline
\end{tabular}

Notes: p-values are given in parentheses. Variables with the suffix “_cs" correspond to cross-sectional average of the variables.

Source: author's calculations.

Table 9: FEER / REER long run relationship

\begin{tabular}{llll}
\hline Mark and Sul & $(2003)$ & & $(2)$ \\
DOLS & logreer & DOLS & logfeer \\
\hline logfeer & $\mathbf{0 . 7 6 6 * * *}$ & logreer & $\mathbf{0 . 3 7 8 * * *}$ \\
& $\mathbf{( 0 . 0 0 0 )}$ & & $\mathbf{( 0 . 0 0 9 )}$ \\
Observations & 624 & Observations & 624 \\
\hline
\end{tabular}

Notes: p-values are given in parentheses. We use a DOLS estimator with heterogeneous time trend, common time effect. The number of differenced lags / leads used is equal to 2 .

Source: author's calculations. 
realignments are still proposed to ensure global macroeconomic stability. These currencies realignments are based on equilibrium (or reference) rates derived from equilibrium exchange rate models.

Driver and Westaway (2005) quote 14 different approaches to estimate equilibrium exchange rates. They underline that the relative relevance of an approach must be considered in the perspective of the question that the approach tries to tackle. When the question at hand is the reduction of global imbalances, the FEER approach seems to be a natural candidate as its relevant time horizon is the medium run and as it requires any assumption on the stationarity of misalignments.

Nevertheless, the FEER suffers from its own limitations. This approach is often labelled as normative mainly because the equilibrium is not uniquely determined. We provide robust empirical evidences that there is a positive bidirectional long run relationship between FEERs and REERs in a non-stationary panel context with heterogeneous slopes and cross-sectional dependencies. These empirical results are supportive of the usefulness of the FEER approach to correct misalignments and in this way reduce current account imbalances and associated risks among the main areas of the world.

As noted by Zhou (1993), an international monetary cooperation, aimed at reducing global imbalances, could not be based on equilibrium exchange rates which are not related either in the short or in the long to the observed exchange rates. Our results provide empirical evidences that exchange rates return to their fundamentals values as in Mark and Choi (1997) and Mark and Sul (2001). Besides, as the return to the equilibrium is quite slow (almost eight years in case of cyclical evolution of competitiveness), our results could be seen as a justification to intervene on foreign exchange markets to realign exchange rates in order to reduce global imbalances and associated risks.

In July 2012, the International Monetary Fund has adopted the FEER concept to strengthen its surveillance activities on bilateral and multilateral levels (International Monetary Fund, 2012). In its Pilot External Sector Report, the International Monetary Fund produce a set of deviations between real effective exchange rates and those consistent with fundamental and desirable policies for 28 economies. This new decision does not create new formal obligations. However, it could be considered as a step in the recognition that members must have mutually consistent objectives to ensure global macroeconomic and macrofinancial stability.

Our empirical results are consistent with the International Monetary Fund's decision as they support the usefulness of the FEER approach to reduce global imbalances. In spite of a number of reservations on the Fund's methodology (Cline and Williamson, 2012), this decision could be preliminary step towards a larger discussion on the future of the international monetary system. 


\section{References}

Barisone, G., R. L. Driver, and S. Wren-Lewis (2006). Are our FEERs justified? Journal of International Money and Finance 25(5), 741-759.

Binder, M. and C. J. Offermanns (2007). International investment positions and exchange rate dynamics: a dynamic panel analysis. Discussion Paper Series 1: Economic Studies 23, Deutsche Bundesbank, Research Centre.

Blanchard, O. and G. M. Milesi-Ferretti (2012). (Why) should current account balances be reduced? IMF Economic Review 60(1), 139-150.

Breitung, J. and S. Das (2005). Panel unit root tests under cross-sectional dependence. Statistica Neerlandica 59(4), 414-433.

Carton, B. and K. Hervé (2012). Estimation of consistent multi-country FEERs. Economic Modelling 29, 1205-1214.

Cassel, G. (1918). Abnormal deviations in international exchanges. The Economic Journal 112, 413-415.

Ca' Zorzi, M., A. Chudik, and A. Dieppe (2012). Thousands of models, one story: current account imbalances in the global economy. Journal of International Money and Finance 31 (6), 1319-1338.

Cheung, Y.-W., M. Chinn, and E. Fujii (2009). Pitfalls in measuring exchange rate misalignment. Open Economies Review 20(2), 183-206.

Chinn, M., B. Eichengreen, and H. Ito (2013). A forensic analysis of global imbalances. Oxford Economic Papers forthcoming.

Chinn, M. and E. Prasad (2003). Medium term determinants of current accounts in industrial and developing countries: an empirical exploration. Journal of International Economics 59(1), 47-76.

Clark, P. and R. MacDonald (1998). Exchange rates and economic fundamentals - a methodological comparison of BEERs and FEERs. Working paper 98/67, International Monetary Fund.

Cline, W. R. (2008). Estimating consistent fundamental equilibrium exchange rates. Working paper 08-6, Peterson Institute for International Economics.

Cline, W. R. and J. H. Williamson (2012). Updated estimates of fundamental equilibrium exchange rates. Policy brief 12-23, Peterson Institute for International Economics. 
Driver, R. L. and P. F. Westaway (2005). Concepts of equilibrium exchange rates. Working paper 248, Bank of England.

Dunaway, S., L. Leigh, and X. Li (2009). How robust are estimates of equilibrium real exchange rates: the case of China. Pacific Economic Review 14(3), 361375.

Duwicquet, V., J. Mazier, and J. Saadaoui (2013). Désajustements de change, fédéralisme budgétaire et redistribution. Revue de l'OFCE 127, 57-96.

Feldstein, M. (2011). The role of currency realignments in eliminating the us and china current account imbalances. Journal of Policy Modeling 33(5), 731-736.

Gagnon, J. E. (2011). Current account imbalances coming back. Working paper 11-1, Peterson Institute for International Economics.

Granger, C. W. J. and P. Newbold (1974). Spurious regressions in econometrics. Journal of Econometrics 2(2), 111-120.

International Monetary Fund (2012). Pilot external sector report. Technical report, International Monetary Fund.

Jeong, S.-E., J. Mazier, and J. Saadaoui (2010). Exchange rate misalignments at world and European levels: a FEER approach. Économie Internationale 121(3), $25-58$.

Kao, C. and M.-H. Chiang (2000). The local power of some unit root tests for panel data. In Advances in Econometrics, Vol. 15: Nonstationary Panels, Panel Cointegration, and Dynamic Panels, pp. 179-222. JAI Press.

Kapetanios, G., M. H. Pesaran, and T. Yamagata (2011). Panels with nonstationary multifactor error structures. Journal of Econometrics 160(2), 326348.

Keynes, J. M. (1936). The general theory of employment, interest, and money. Harcourt Brace.

López-Villavicencio, A., J. Mazier, and J. Saadaoui (2012). Temporal dimension and equilibrium exchange rate: a FEER / BEER comparison. Emerging Markets Review 13(1), 58-77.

Mark, N. C. and D.-Y. Choi (1997). Real exchange-rate prediction over long horizons. Journal of International Economics 43(1-2), 29-60. 
Mark, N. C. and D. Sul (2001, February). Nominal exchange rates and monetary fundamentals: Evidence from a small post-bretton woods panel. Journal of International Economics 53(1), 29-52.

Mark, N. C. and D. Sul (2003). Cointegration vector estimation by panel DOLS and long-run money demand. Oxford Bulletin of Economics and Statistics 65(5), 655-680.

Pedroni, P. (1999). Critical values for cointegration tests in heterogeneous panels with multiple regressors. Oxford Bulletin of Economics and Statistics 61(S1), 653-670.

Persyn, D. and J. Westerlund (2008). Error-correction based cointegration tests for panel data. Stata Journal 8(2), 232-241.

Pesaran, M. H. (2006). Estimation and inference in large heterogeneous panels with a multifactor error structure. Econometrica 74(4), 967-1012.

Pesaran, M. H. (2007). A simple panel unit root test in the presence of cross-section dependence. Journal of Applied Econometrics 22(2), 265-312.

Pesaran, M. H., Y. Shin, and R. P. Smith (1999). Pooled mean group estimation of dynamic heterogeneous panels. Journal of the American Statistical Association 94(446), 621-634.

Saadaoui, J. (2011). Exchange rate dynamics and fundamental equilibrium exchange rates. Economics Bulletin 31(3), 1993-2005.

Schnatz, B. (2011). Global imbalances and the pretence of knowing fundamental equilibrium exchange rates. Pacific Economic Review 16(5), 604-615.

Stein, J. L. and P. R. Allen (1998, October). Fundamental determinants of exchange rates. Oxford University Press.

Westerlund, J. (2007). Testing for error correction in panel data. Oxford Bulletin of Economics and Statistics 69(6), 709-748.

Williamson, J. (1994). Estimating equilibrium exchange rates. Peterson Institute for International Economics.

You, K. and N. Sarantis (2011). Structural breaks and the equilibrium chinese yuan/us dollar real exchange rate: a FEER approach. Review of International Economics 19(5), 791-808.

Zhou, S. (1993). Fundamental equilibrium exchange rates and exchange rate dynamics. Open Economies Review 4(2), 189-209. 


\section{A Country List}

Table A.1: Country list

\begin{tabular}{lll}
\hline & Code & Country \\
\hline 1 & ARG & Argentina \\
2 & AUT & Austria \\
3 & BRA & Brazil \\
4 & CHL & Chile \\
5 & CHN & China \\
6 & COL & Colombia \\
7 & FIN & Finland \\
8 & FRA & France \\
9 & GER & Germany \\
10 & GRC & Greece \\
11 & IND & India \\
12 & INS & Indonesia \\
13 & IRL & Ireland \\
14 & ITA & Italy \\
15 & JPN & Japan \\
16 & KOR & Republic of Korea \\
17 & MEX & Mexico \\
18 & MYS & Malaysia \\
19 & NLD & Netherlands \\
20 & PHL & Philippines \\
21 & PRT & Portugal \\
22 & SPA & Spain \\
23 & THA & Thailand \\
24 & UK & United Kingdom of Great Britain and Northern Ireland \\
25 & URU & Uruguay \\
26 & USA & United States of America \\
\hline & &
\end{tabular}




\section{B Misalignments, REERs and FEERs}

Figure B.1: Misalignments, REERs and FEERs

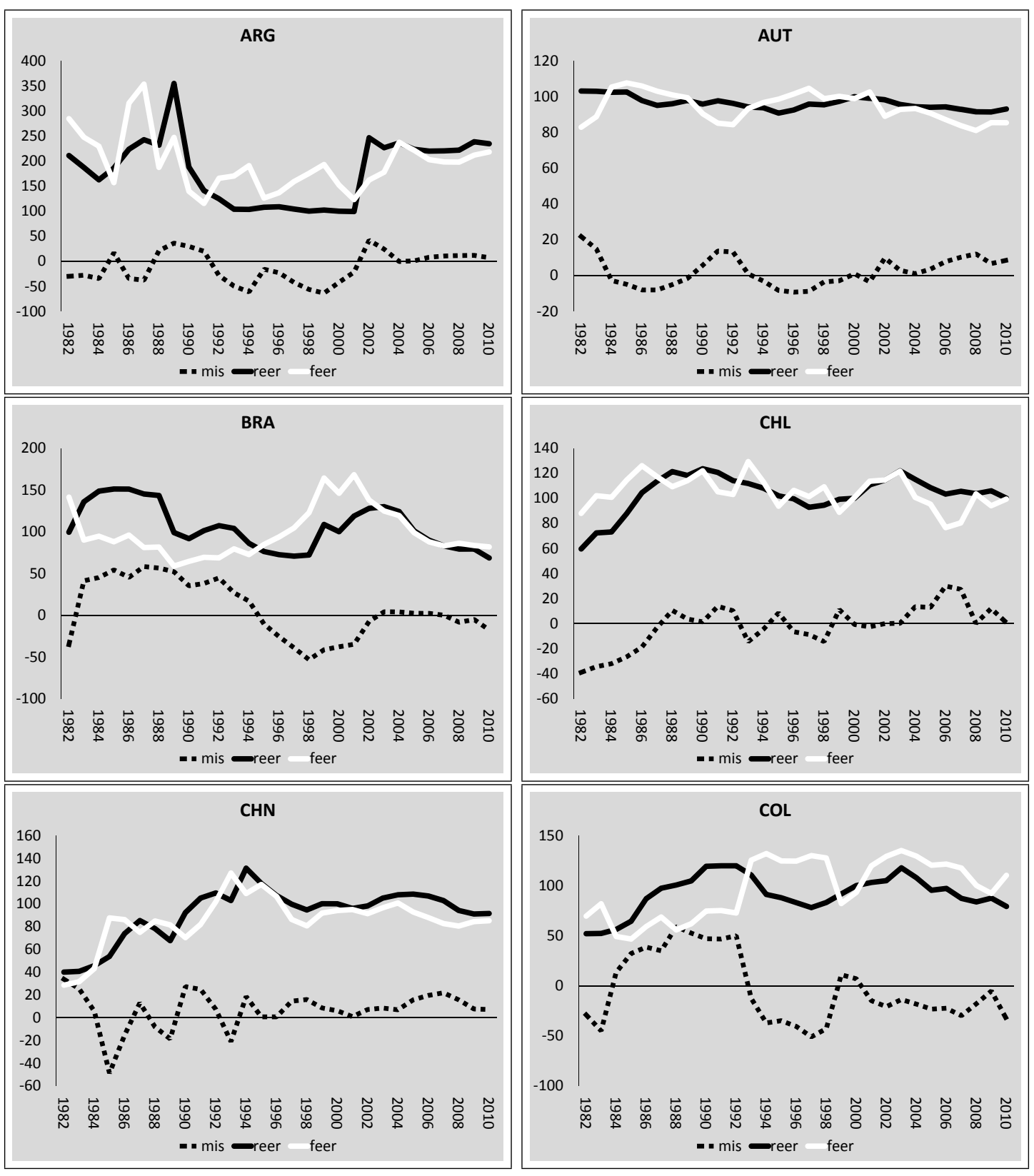


Figure B.2: Misalignments, REERs and FEERs (continued)

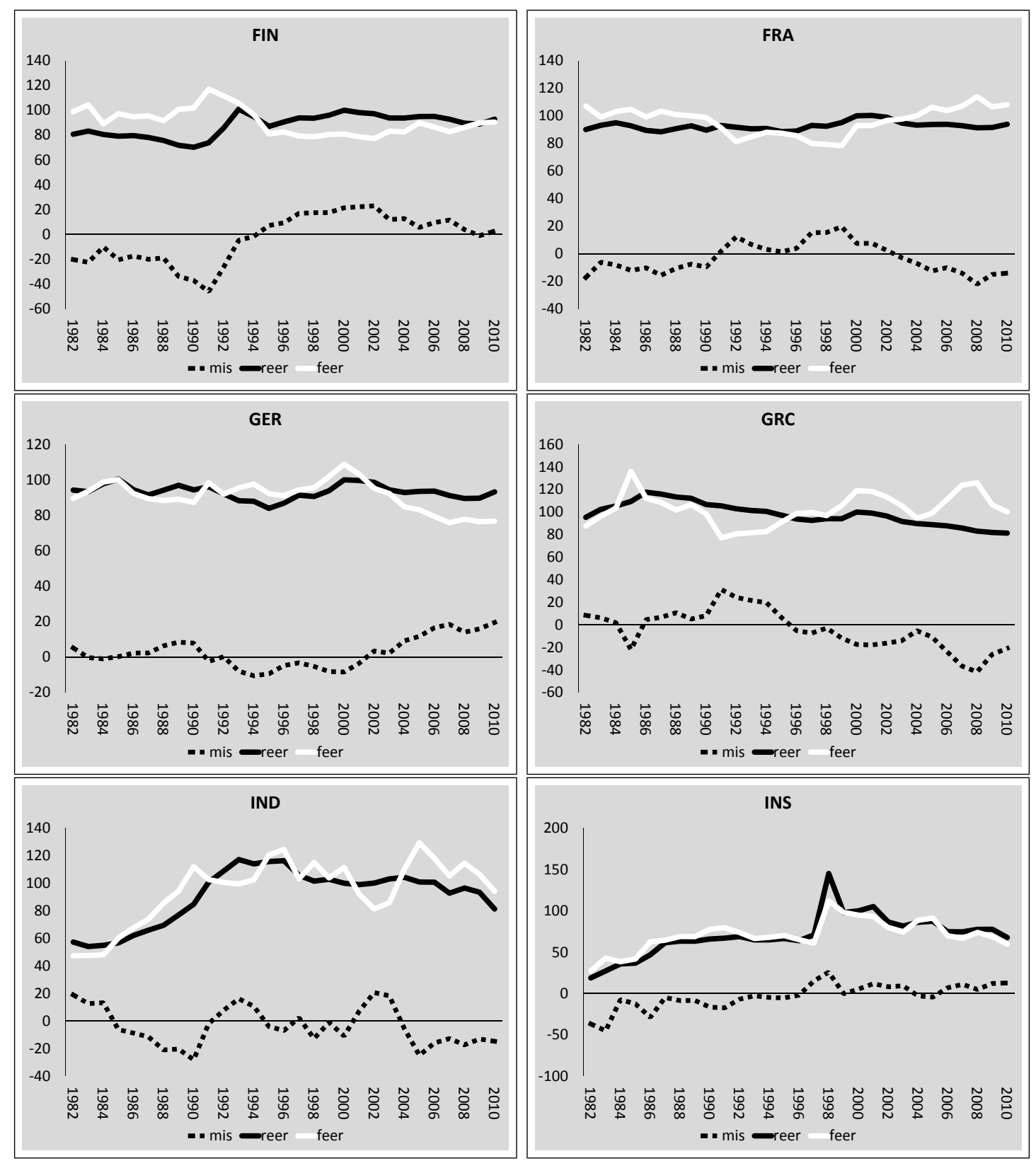


Figure B.3: Misalignments, REERs and FEERs (continued)

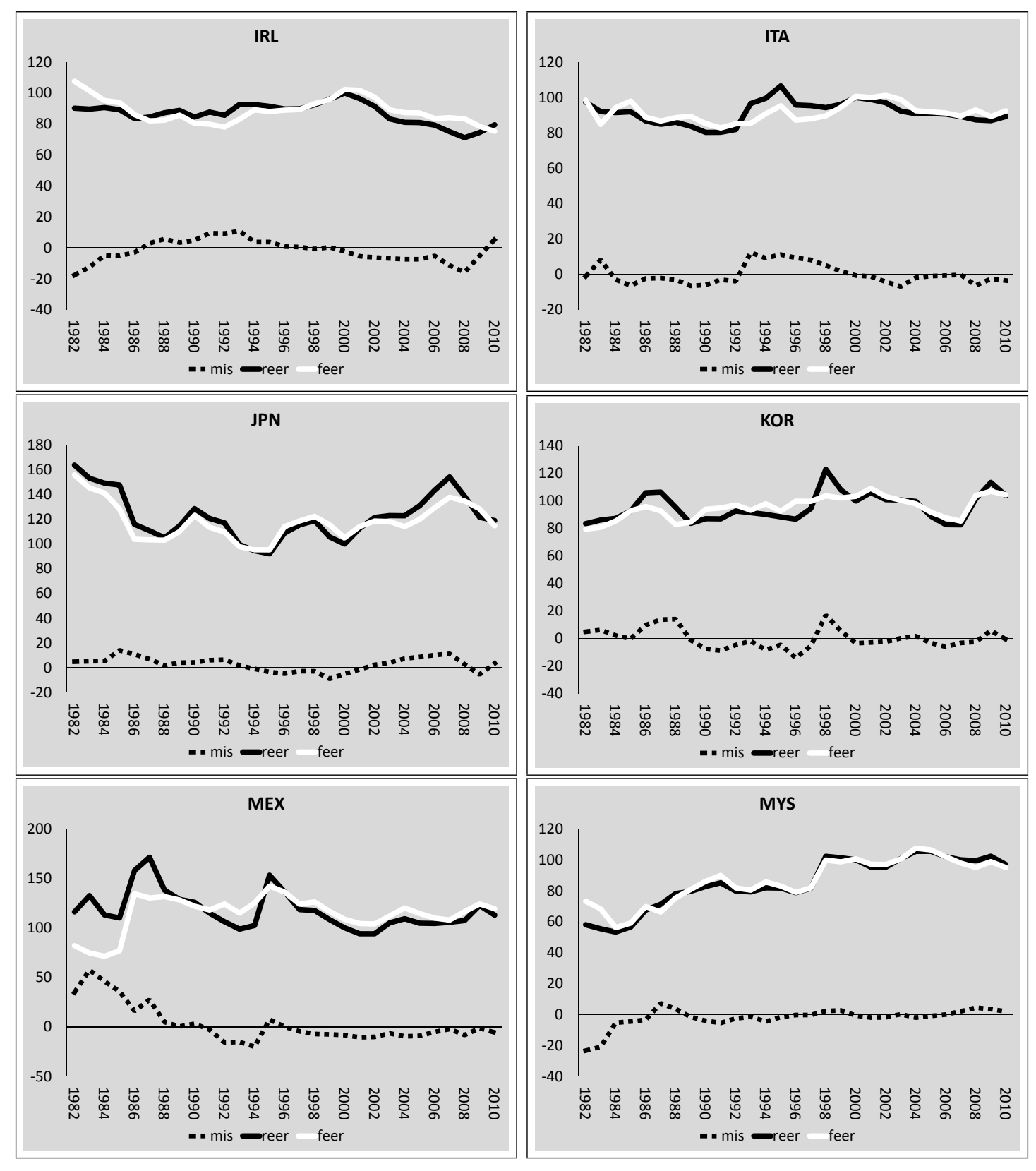


Figure B.4: Misalignments, REERs and FEERs (continued)

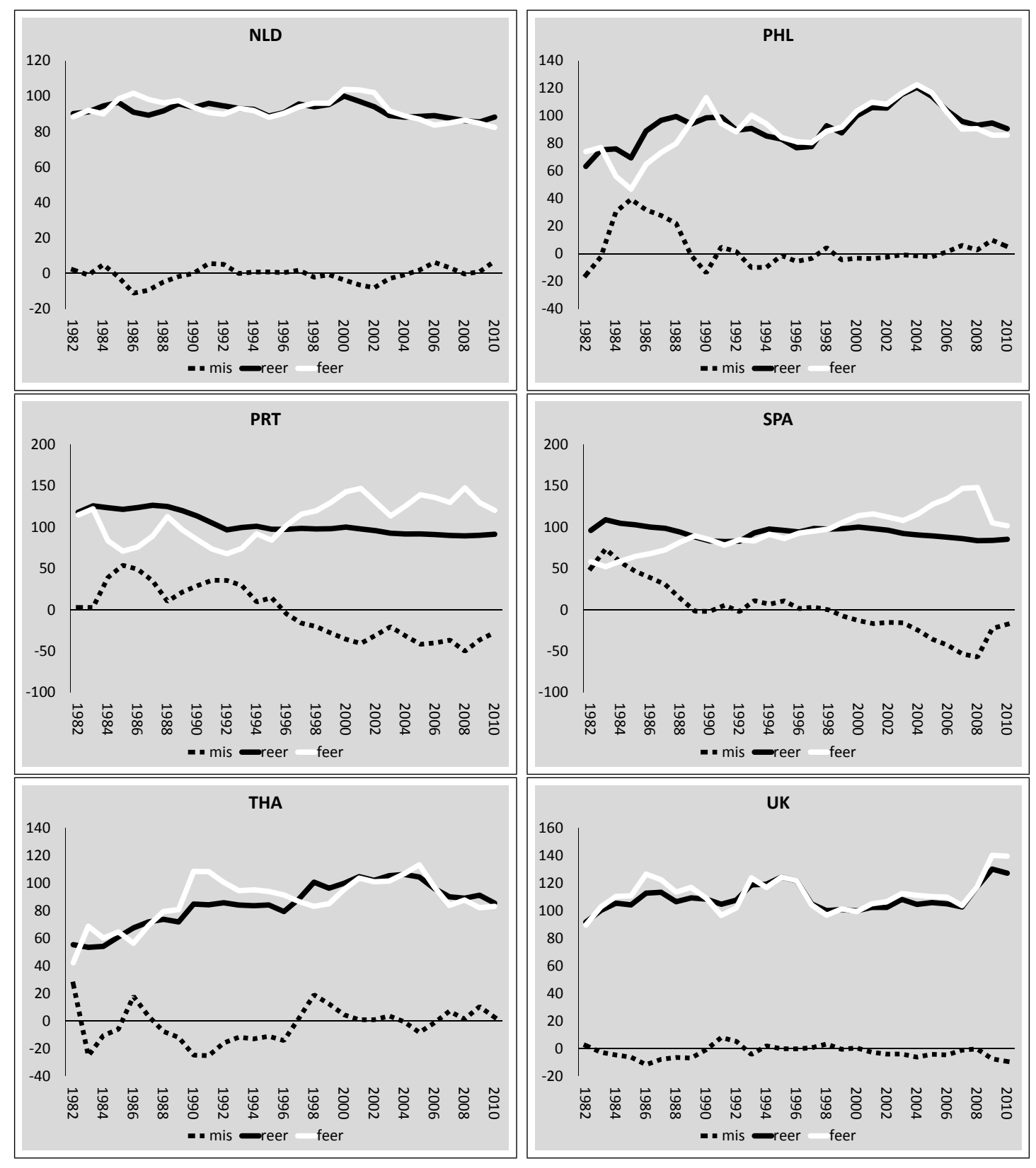


Figure B.5: Misalignments, REERs and FEERs (continued)

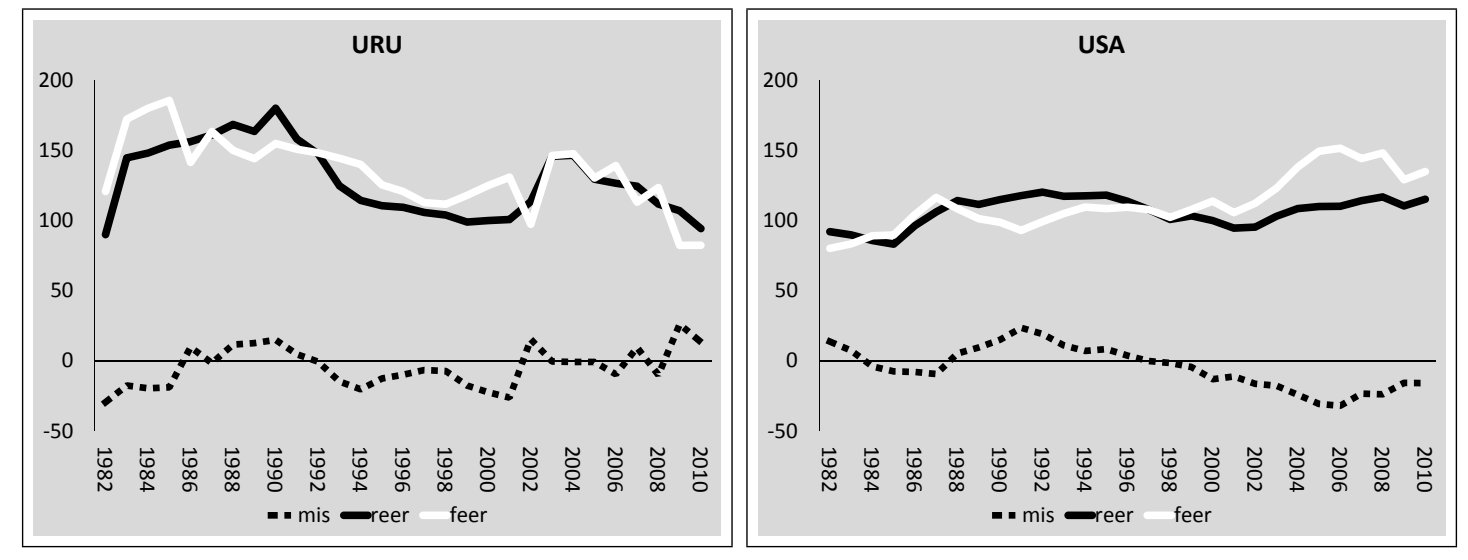

Source: author's calculation for misalignments (in \%) and BIS, IFS, Bruegel for real effective exchange rates $(2000=100)$. An increase (decrease) of the real effective exchange rate corresponds to a depreciation (appreciation). A positive (negative) exchange rate misalignment corresponds to an undervaluation (overvaluation). 


\section{C a CPMG approach}

We implement a cross sectionally augmented pooled mean group (CPMG) estimator (Pesaran et al., 1999, Pesaran, 2006; Binder and Offermanns, 2007). In this approach, we augment the PMG estimator with cross sectional average of independent and dependent variables in order to capture the common factors or the heterogeneous time effects.

More precisely, we start with the $\operatorname{ARDL}(1,1)^{16}$ model as specified in equation (C.1):

$$
\operatorname{reer}_{i, t}=\delta_{0 i}+\delta_{1 i} \text { feer }_{i, t}+\delta_{2 i} \text { feer }_{i, t-1}+\lambda_{i} \text { reer }_{i, t-1}+u_{i, t}
$$

The error correction equation yield:

$$
\Delta \text { reer }_{i, t}=\phi_{i}\left(\text { reer }_{i, t-1}-\theta_{0 i}-\theta_{1 i} \text { feer }_{i, t}\right)-\delta_{2 i} \Delta \text { feer }_{i, t}+u_{i, t}
$$

Now, we assume that the error term $u_{i, t}$ follow multi-factor error structure:

$$
u_{i, t}=\gamma_{i} f_{t}+\varepsilon_{i, t}
$$

Where $f_{t}$ is a factor of unobserved common shocks. The error terms dependencies across individuals are captured by $f$, whereas the impacts of these factors on each country are governed by the idiosyncratic loadings in $\gamma_{i}$. By using equation (C.1) and (C.3) and by averaging across $i$, we obtain:

$$
\overline{r e e r}_{t}=\bar{\delta}_{0}+\bar{\delta}_{1} \overline{f e e r}_{t}+\bar{\delta}_{2} \overline{f e e r}_{t-1}+\bar{\lambda} \overline{r e e r}_{t-1}+\bar{\gamma} f_{t}+\bar{\varepsilon}_{t}
$$

Where the variables with a bar denote the simple cross section averages of the corresponding variables in year $t$. The common factors can be captured through a linear combination of the cross-sectional averages of the dependent variable and of the regressors:

$$
\gamma_{i} f_{t}=-c_{i} \bar{\delta}_{0}-c_{i}\left(\bar{\delta}_{1}+\bar{\delta}_{2}\right) \overline{f e e r}_{t}+c_{i}(1-\bar{\lambda}) \overline{r e e r}_{t-1}+c_{i} \Delta \overline{r e e r}_{t}+c_{i} \bar{\delta}_{2} \Delta \overline{f e e r}_{t}
$$

Where $c_{i}=\frac{\gamma_{i}}{\bar{\gamma}}$. Replacing equation $($ C.3 and C.5 in equation (C.2) yields the error correction equation:

$$
\begin{aligned}
\Delta \text { reer }_{i, t} & =\phi_{i}\left(\text { reer }_{i, t-1}-\theta_{0 i}-\theta_{1 i} \text { feer }_{i, t}-a_{i}^{*} \overline{r e e r}_{t-1}+b_{i}^{*} \overline{f e e r}_{t}\right) \\
& -\delta_{2 i} \Delta \text { feer }_{i, t}+c_{i} \Delta \overline{\text { reer }}_{t}+c_{i}^{*} \Delta \overline{\text { feer }}_{t}+\varepsilon_{i, t}
\end{aligned}
$$

With $\phi_{i}=-\left(1-\lambda_{i}\right) ; \theta_{0 i}=\left(\delta_{0 i}-c_{i} \bar{\delta}_{0}\right) /\left(1-\lambda_{i}\right) ; \theta_{1 i}=\left(\delta_{1 i}+\delta_{2 i}\right) /\left(1-\lambda_{i}\right) ;$ $a_{i}^{*}=c_{i}(1-\bar{\lambda}) /\left(1-\lambda_{i}\right) ; b_{i}^{*}=c_{i}\left(\bar{\delta}_{1}+\bar{\delta}_{2}\right) /\left(1-\lambda_{i}\right) ; c_{i}^{*}=c_{i} \bar{\delta}_{2}$.

\footnotetext{
${ }^{16}$ Autoregressive Distributed Lags.
} 
Since the CPMG estimator imposes long-run coefficients to be constant for all individuals, while it allows short run heterogeneity, the error correction model is written:

$$
\begin{aligned}
\Delta \text { reer }_{i, t} & =\phi\left(\text { reer }_{i, t-1}-\theta_{0}-\theta_{1} \text { feer }_{i, t}-a^{*} \overline{r e e r}_{t-1}+b^{*} \overline{f e e r}_{t}\right) \\
& -\delta_{2 i} \Delta \text { feer }_{i, t}+c_{i} \Delta \overline{\text { reer }}_{t}+c_{i}^{*} \Delta \overline{\text { feer }}_{t}+\varepsilon_{i, t} \\
\Delta \text { feer }_{i, t} & =\phi\left(\text { feer }_{i, t-1}-\theta_{0}-\theta_{1} \text { reer }_{i, t}-a^{*} \overline{f e e r}_{t-1}+b^{*} \overline{r e e r}_{t}\right) \\
& -\delta_{2 i} \Delta \text { reer }_{i, t}+c_{i} \Delta \overline{\text { feer }}_{t}+c_{i}^{*} \Delta \overline{\text { reer }}_{t}+\varepsilon_{i, t}
\end{aligned}
$$




\section{Short run dynamics}

Table D.1: Short Run Dynamics (CPMG)

\begin{tabular}{|c|c|c|c|c|c|c|c|}
\hline CPMG & $\begin{array}{l}\text { (1) } \\
\text { D.logreer }\end{array}$ & $\begin{array}{l}(2) \\
\text { ARG }\end{array}$ & $\begin{array}{l}\text { (3) } \\
\text { AUT }\end{array}$ & $\begin{array}{l}\text { (4) } \\
\text { BRA }\end{array}$ & $\begin{array}{l}(5) \\
\text { CHL }\end{array}$ & $\begin{array}{l}\text { (6) } \\
\text { CHN }\end{array}$ & $\begin{array}{l}\text { (7) } \\
\text { COL }\end{array}$ \\
\hline EC & & $\begin{array}{l}-0.189 * \\
(0.093)\end{array}$ & $\begin{array}{l}-0.112 * * \\
(0.047)\end{array}$ & $\begin{array}{l}-0.170^{* *} \\
(0.029)\end{array}$ & $\begin{array}{l}-0.206 * * * \\
(0.000)\end{array}$ & $\begin{array}{l}-0.613 * * * \\
(0.000)\end{array}$ & $\begin{array}{l}0.158 * * * \\
(0.009)\end{array}$ \\
\hline D.logfeer & & $\begin{array}{l}0.351^{* *} \\
(0.015)\end{array}$ & $\begin{array}{l}-0.020 \\
(0.717)\end{array}$ & $\begin{array}{l}0.215 \\
(0.215)\end{array}$ & $\begin{array}{l}0.0480 \\
(0.570)\end{array}$ & $\begin{array}{l}-0.364 * * * \\
(0.001)\end{array}$ & $\begin{array}{l}-0.0841 \\
(0.264)\end{array}$ \\
\hline D.logreer_cs & & $\begin{array}{l}3.830 * * * \\
(0.004)\end{array}$ & $\begin{array}{l}-0.139 \\
(0.271)\end{array}$ & $\begin{array}{l}2.473 * * * \\
(0.008)\end{array}$ & $\begin{array}{l}0.993^{* *} \\
(0.012)\end{array}$ & $\begin{array}{l}-0.752 \\
(0.247)\end{array}$ & $\begin{array}{l}2.374 * * * \\
(0.000)\end{array}$ \\
\hline D.logfeer_cs & & $\begin{array}{l}-2.945^{* *} \\
(0.010)\end{array}$ & $\begin{array}{l}-0.136 \\
(0.182)\end{array}$ & $\begin{array}{l}-0.892 \\
(0.214)\end{array}$ & $\begin{array}{l}-0.291 \\
(0.328)\end{array}$ & $\begin{array}{l}-0.317 \\
(0.536)\end{array}$ & $\begin{array}{l}0.240 \\
(0.610)\end{array}$ \\
\hline logfeer & $\begin{array}{l}0.738 * * * \\
(0.000)\end{array}$ & & & & & & \\
\hline L.logreer_cs & $\begin{array}{l}-0.028 \\
(0.860)\end{array}$ & & & & & & \\
\hline logfeer_cs & $\begin{array}{l}-0.187 \\
(0.109)\end{array}$ & & & & & & \\
\hline Constant & & $\begin{array}{l}0.430 \\
(0.129)\end{array}$ & $\begin{array}{l}0.246^{*} \\
(0.088)\end{array}$ & $\begin{array}{l}0.374 * \\
(0.073)\end{array}$ & $\begin{array}{l}0.467 * * * \\
(0.009)\end{array}$ & $\begin{array}{l}1.392 * * * \\
(0.002)\end{array}$ & $\begin{array}{l}-0.332 * * \\
(0.044)\end{array}$ \\
\hline CPMG & $\begin{array}{l}\text { (1) } \\
\text { D.logreer }\end{array}$ & $\begin{array}{l}\text { (8) } \\
\text { FIN }\end{array}$ & $\begin{array}{l}(9) \\
\text { FRA }\end{array}$ & $\begin{array}{l}(10) \\
\text { GER }\end{array}$ & $\begin{array}{l}(11) \\
\text { GRC }\end{array}$ & $\begin{array}{l}\text { (12) } \\
\text { IND }\end{array}$ & $\begin{array}{l}\text { (13) } \\
\text { INS }\end{array}$ \\
\hline$\overline{E C}$ & & $\begin{array}{l}-0.094 * \\
(0.061)\end{array}$ & $\begin{array}{l}0.024 \\
(0.676)\end{array}$ & $\begin{array}{l}-0.0936 \\
(0.205)\end{array}$ & $\begin{array}{l}-0.009 \\
(0.778)\end{array}$ & $\begin{array}{l}-0.233 * * * \\
(0.008)\end{array}$ & $\begin{array}{l}0.266 * * * \\
(0.005)\end{array}$ \\
\hline D.logfeer & & $\begin{array}{l}0.0037 \\
(0.978)\end{array}$ & $\begin{array}{l}0.030 \\
(0.709)\end{array}$ & $\begin{array}{l}0.284 * * \\
(0.013)\end{array}$ & $\begin{array}{l}0.066 \\
(0.156)\end{array}$ & $\begin{array}{l}0.012 \\
(0.910)\end{array}$ & $\begin{array}{l}0.551 * * * \\
(0.001)\end{array}$ \\
\hline D. logreer_cs & & $\begin{array}{l}-0.564 \\
(0.105)\end{array}$ & $\begin{array}{l}-0.026 \\
(0.881)\end{array}$ & $\begin{array}{l}-0.0861 \\
(0.645)\end{array}$ & $\begin{array}{l}0.642 * * * \\
(0.000)\end{array}$ & $\begin{array}{l}-0.065 \\
(0.876)\end{array}$ & $\begin{array}{l}0.283 \\
(0.744)\end{array}$ \\
\hline D.logfeer_cs & & $\begin{array}{l}0.545^{*} \\
(0.054)\end{array}$ & $\begin{array}{l}-0.227 \\
(0.130)\end{array}$ & $\begin{array}{l}-0.257^{*} \\
(0.082)\end{array}$ & $\begin{array}{l}0.100 \\
(0.506)\end{array}$ & $\begin{array}{l}0.287 \\
(0.423)\end{array}$ & $\begin{array}{l}-0.329 \\
(0.612)\end{array}$ \\
\hline logfeer & $\begin{array}{l}0.738 * * * \\
(0.000)\end{array}$ & & & & & & \\
\hline L.logreer_cs & $\begin{array}{l}-0.028 \\
(0.860)\end{array}$ & & & & & & \\
\hline logfeer_cs & $\begin{array}{l}-0.187 \\
(0.109)\end{array}$ & & & & & & \\
\hline Constant & & $\begin{array}{l}0.207 * \\
(0.092)\end{array}$ & $\begin{array}{l}-0.049 \\
(0.692)\end{array}$ & $\begin{array}{l}0.209 \\
(0.224)\end{array}$ & $\begin{array}{l}0.012 \\
(0.870)\end{array}$ & $\begin{array}{l}0.508^{* *} \\
(0.033)\end{array}$ & $\begin{array}{l}0.575 * * \\
(0.022)\end{array}$ \\
\hline & & (14) & (15) & (16) & (17) & $(18)$ & (19) \\
\hline CPMG & D. logreer & IRL & ITA & JPN & KOR & MEX & MYS \\
\hline EC & & $\begin{array}{l}-0.205 * \\
(0.099)\end{array}$ & $\begin{array}{l}-0.226 * \\
(0.085)\end{array}$ & $\begin{array}{l}-0.163 \\
(0.154)\end{array}$ & $\begin{array}{l}-0.588 * * * \\
(0.000)\end{array}$ & $\begin{array}{l}-0.305^{* * *} \\
(0.003)\end{array}$ & $\begin{array}{l}-0.138 * * \\
(0.029)\end{array}$ \\
\hline D.logfeer & & $\begin{array}{l}0.539 * * * \\
(0.000)\end{array}$ & $\begin{array}{l}0.351 * * \\
(0.016)\end{array}$ & $\begin{array}{l}0.854 * * * \\
(0.000)\end{array}$ & $\begin{array}{l}0.214 \\
(0.375)\end{array}$ & $\begin{array}{l}0.474 * * * \\
(0.003)\end{array}$ & $\begin{array}{l}0.598 * * * \\
(0.000)\end{array}$ \\
\hline D.logreer_cs & & $\begin{array}{l}0.037 \\
(0.889)\end{array}$ & $\begin{array}{l}-0.267 \\
(0.346)\end{array}$ & $\begin{array}{l}0.082 \\
(0.791)\end{array}$ & $\begin{array}{l}1.354 * * * \\
(0.000)\end{array}$ & $\begin{array}{l}1.737 * * * \\
(0.009)\end{array}$ & $\begin{array}{l}0.287 \\
(0.230)\end{array}$ \\
\hline D.logfeer_cs & & $\begin{array}{l}-0.270 \\
(0.202)\end{array}$ & $\begin{array}{l}0.204 \\
(0.359)\end{array}$ & $\begin{array}{l}-0.058 \\
(0.815)\end{array}$ & $\begin{array}{l}0.142 \\
(0.674)\end{array}$ & $\begin{array}{l}-0.627 \\
(0.222)\end{array}$ & $\begin{array}{l}0.047 \\
(0.774)\end{array}$ \\
\hline logfeer & $\begin{array}{l}0.738 * * * \\
(0.000)\end{array}$ & & & & & & \\
\hline L.logreer_cs & $\begin{array}{l}-0.028 \\
(0.860)\end{array}$ & & & & & & \\
\hline logfeer_cs & $\begin{array}{l}-0.187 \\
(0.109)\end{array}$ & & & & & & \\
\hline Constant & & $\begin{array}{l}0.445 \\
(0.131)\end{array}$ & $\begin{array}{l}0.491 \\
(0.132)\end{array}$ & $\begin{array}{l}0.371 \\
(0.180)\end{array}$ & $\begin{array}{l}1.284 * * * \\
(0.005)\end{array}$ & $\begin{array}{l}0.676^{* *} \\
(0.029)\end{array}$ & $\begin{array}{l}0.307 * * \\
(0.045)\end{array}$ \\
\hline
\end{tabular}


Table D.2: Short Run Dynamics (CPMG) (continued)

\begin{tabular}{|c|c|c|c|c|c|c|c|}
\hline CPMG & $\begin{array}{l}\text { (1) } \\
\text { D.logreer }\end{array}$ & $\begin{array}{l}(20) \\
\text { NLD }\end{array}$ & $\begin{array}{l}(21) \\
\text { PHL }\end{array}$ & $\begin{array}{l}\text { (22) } \\
\text { PRT }\end{array}$ & $\begin{array}{l}(23) \\
\text { SPA }\end{array}$ & $\begin{array}{l}\text { (24) } \\
\text { THA }\end{array}$ & $\begin{array}{l}\text { (25) } \\
\text { UK }\end{array}$ \\
\hline EC & & $\begin{array}{l}-0.531^{* * *} \\
(0.000)\end{array}$ & $\begin{array}{l}-0.277^{* * *} \\
(0.002)\end{array}$ & $\begin{array}{l}-0.028 \\
(0.118)\end{array}$ & $\begin{array}{l}0.045 \\
(0.258)\end{array}$ & $\begin{array}{l}-0.210 * * \\
(0.011)\end{array}$ & $\begin{array}{l}-0.320 * * \\
(0.016)\end{array}$ \\
\hline D.logfeer & & $\begin{array}{l}0.277^{* *} \\
(0.019)\end{array}$ & $\begin{array}{l}0.206^{* *} \\
(0.031)\end{array}$ & $\begin{array}{l}0.098^{* * *} \\
(0.006)\end{array}$ & $\begin{array}{l}-0.191 * * \\
(0.032)\end{array}$ & $\begin{array}{l}-0.029 \\
(0.726)\end{array}$ & $\begin{array}{l}0.415^{* * *} \\
(0.000)\end{array}$ \\
\hline D.logreer_cs & & $\begin{array}{l}-0.604 * * * \\
(0.000)\end{array}$ & $\begin{array}{l}1.649 * * * \\
(0.000)\end{array}$ & $\begin{array}{l}0.388 * * \\
(0.028)\end{array}$ & $\begin{array}{l}-0.374 \\
(0.300)\end{array}$ & $\begin{array}{l}0.571 \\
(0.148)\end{array}$ & $\begin{array}{l}-0.249 \\
(0.159)\end{array}$ \\
\hline D.logfeer_cs & & $\begin{array}{l}-0.208^{*} \\
(0.077)\end{array}$ & $\begin{array}{l}-0.238 \\
(0.480)\end{array}$ & $\begin{array}{l}0.0310 \\
(0.841)\end{array}$ & $\begin{array}{l}0.459 * \\
(0.072)\end{array}$ & $\begin{array}{l}0.305 \\
(0.331)\end{array}$ & $\begin{array}{l}0.053 \\
(0.678)\end{array}$ \\
\hline logfeer & $\begin{array}{l}0.738 * * * \\
(0.000)\end{array}$ & & & & & & \\
\hline L.logreer_cs & $\begin{array}{l}-0.028 \\
(0.860)\end{array}$ & & & & & & \\
\hline logfeer_cs & $\begin{array}{l}-0.187 \\
(0.109)\end{array}$ & & & & & & \\
\hline Constant & & $\begin{array}{l}1.158^{* *} \\
(0.015)\end{array}$ & $\begin{array}{l}0.617^{* *} \\
(0.018)\end{array}$ & $\begin{array}{l}0.0515 \\
(0.244)\end{array}$ & $\begin{array}{l}-0.100 \\
(0.281)\end{array}$ & $\begin{array}{l}0.458 * * \\
(0.032)\end{array}$ & $\begin{array}{l}0.708 * \\
(0.058)\end{array}$ \\
\hline CPMG & & $\begin{array}{l}\text { (1) } \\
\text { D.logreer }\end{array}$ & & $\begin{array}{l}(26) \\
\text { URU }\end{array}$ & & $\begin{array}{l}\text { (27) } \\
\text { USA }\end{array}$ & \\
\hline EC & & & & $\begin{array}{c}-0.185 * \\
(0.085)\end{array}$ & & $\begin{array}{l}-0.110 \\
(0.128)\end{array}$ & \\
\hline D.logfeer & & & & $\begin{array}{l}0.342 * * * \\
(0.001)\end{array}$ & & $\begin{array}{l}0.341^{* *} \\
(0.026)\end{array}$ & \\
\hline D.logreer_cs & & & & $\begin{array}{l}2.649 * * * \\
(0.000)\end{array}$ & & $\begin{array}{l}-0.066 \\
(0.831)\end{array}$ & \\
\hline D.logfeer_cs & & & & $\begin{array}{l}-1.423 * * * \\
(0.000)\end{array}$ & & $\begin{array}{l}-0.126 \\
(0.664)\end{array}$ & \\
\hline logfeer & & $\begin{array}{l}0.738 * * * \\
(0.000)\end{array}$ & & & & & \\
\hline L.logreer_cs & & $\begin{array}{l}-0.028 \\
(0.860)\end{array}$ & & & & & \\
\hline logfeer_cs & & $\begin{array}{l}-0.187 \\
(0.109)\end{array}$ & & & & & \\
\hline Constant & & & & $\begin{array}{l}0.416 \\
(0.115)\end{array}$ & & $\begin{array}{l}0.241 \\
(0.172)\end{array}$ & \\
\hline
\end{tabular}

Notes: $p$-values are given in parentheses. $\mathrm{D}$ is the difference estimator, $\mathrm{L}$ is the lag operator, $\mathrm{EC}$ corresponds to the error correction term and the country name stands for the heterogeneous dynamic part of the error correction model. Variables with the suffix "_cs" correspond to cross-sectional average of the variables.

Source: author's calculations. 
Table D.3: Short Run Dynamics (CPMG)

\begin{tabular}{|c|c|c|c|c|c|c|c|}
\hline CPMG & $\begin{array}{l}(1) \\
\text { D.logfeer }\end{array}$ & $\begin{array}{l}(2) \\
\text { ARG }\end{array}$ & $\begin{array}{l}\text { (3) } \\
\text { AUT }\end{array}$ & $\begin{array}{l}(4) \\
\text { BRA }\end{array}$ & $\begin{array}{l}\text { (5) } \\
\text { CHL }\end{array}$ & $\begin{array}{l}(6) \\
\text { CHN }\end{array}$ & $\begin{array}{l}(7) \\
\text { COL }\end{array}$ \\
\hline EC & & $\begin{array}{l}-0.546 * * * \\
(0.000)\end{array}$ & $\begin{array}{l}-0.352^{* * * *} \\
(0.001)\end{array}$ & $\begin{array}{l}-0.087 \\
(0.370)\end{array}$ & $\begin{array}{l}-0.516 * * * \\
(0.000)\end{array}$ & $\begin{array}{l}-0.628 * * * \\
(0.000)\end{array}$ & $\begin{array}{l}-0.394 * * * \\
(0.000)\end{array}$ \\
\hline D.logreer & & $\begin{array}{l}0.113 \\
(0.540)\end{array}$ & $\begin{array}{l}0.145 \\
(0.785)\end{array}$ & $\begin{array}{l}0.459 * * * \\
(0.009)\end{array}$ & $\begin{array}{l}0.702 * * \\
(0.014)\end{array}$ & $\begin{array}{l}-0.055 \\
(0.810)\end{array}$ & $\begin{array}{l}-1.247^{* * *} \\
(0.001)\end{array}$ \\
\hline D.logfeer_cs & & $\begin{array}{l}3.676 * * * \\
(0.000)\end{array}$ & $\begin{array}{l}0.462 \\
(0.139)\end{array}$ & $\begin{array}{l}31 / 12 / 20 \\
(0.127)\end{array}$ & $\begin{array}{l}1.778 * * * \\
(0.000)\end{array}$ & $\begin{array}{l}31 / 12 / 32 \\
(0.216)\end{array}$ & $\begin{array}{l}1.785 * * \\
(0.043)\end{array}$ \\
\hline D.logreer_cs & & $\begin{array}{l}0.599 \\
(0.688)\end{array}$ & $\begin{array}{l}0.052 \\
(0.893)\end{array}$ & $\begin{array}{l}-2.832^{* * *} \\
(0.007)\end{array}$ & $\begin{array}{l}-0.158 \\
(0.852)\end{array}$ & $\begin{array}{l}0.002 \\
(0.998)\end{array}$ & $\begin{array}{l}31 / 01 / 47 \\
(0.101)\end{array}$ \\
\hline logreer & $\begin{array}{l}0.698 * * * \\
(0.000)\end{array}$ & & & & & & \\
\hline L.logfeer_cs & $\begin{array}{l}0.426 * * * \\
(0.000)\end{array}$ & & & & & & \\
\hline logreer_cs & $\begin{array}{l}-0.649 * * * \\
(0.000)\end{array}$ & & & & & & \\
\hline Constant & & $\begin{array}{l}1.444^{* * *} \\
(0.005)\end{array}$ & $\begin{array}{l}0.840^{* *} \\
(0.013)\end{array}$ & $\begin{array}{l}0.198 \\
(0.401)\end{array}$ & $\begin{array}{l}1.240 * * * \\
(0.009)\end{array}$ & $\begin{array}{l}1.474 * * * \\
(0.004)\end{array}$ & $\begin{array}{l}0.967 * * * \\
(0.006) \\
\end{array}$ \\
\hline CPMG & $\begin{array}{l}(1) \\
\text { D.logfeer }\end{array}$ & $\begin{array}{l}(8) \\
\text { FIN }\end{array}$ & $\begin{array}{l}(9) \\
\text { FRA }\end{array}$ & $\begin{array}{l}(10) \\
\text { GER }\end{array}$ & $\begin{array}{l}(11) \\
\text { GRC }\end{array}$ & $\begin{array}{l}\text { (12) } \\
\text { IND }\end{array}$ & $\begin{array}{l}\text { (13) } \\
\text { INS }\end{array}$ \\
\hline EC & & $\begin{array}{l}-0.032 \\
(0.662)\end{array}$ & $\begin{array}{l}-0.148 \\
(0.105)\end{array}$ & $\begin{array}{l}-0.072 \\
(0.459)\end{array}$ & $\begin{array}{l}-0.233 * \\
(0.053)\end{array}$ & $\begin{array}{l}-0.373^{* * *} \\
(0.006)\end{array}$ & $\begin{array}{l}-0.504 * * * \\
(0.006)\end{array}$ \\
\hline D.logreer & & $\begin{array}{l}0.160 \\
(0.539)\end{array}$ & $\begin{array}{l}-0.137 \\
(0.760)\end{array}$ & $\begin{array}{l}0.902 * * * \\
(0.000)\end{array}$ & $\begin{array}{l}0.839 \\
(0.243)\end{array}$ & $\begin{array}{l}0.432 \\
(0.129)\end{array}$ & $\begin{array}{l}0.291 * \\
(0.067)\end{array}$ \\
\hline D. logfeer_cs & & $\begin{array}{l}0.177 \\
(0.684)\end{array}$ & $\begin{array}{l}0.293 \\
(0.387)\end{array}$ & $\begin{array}{l}0.281 \\
(0.268)\end{array}$ & $\begin{array}{l}0.088 \\
(0.879)\end{array}$ & $\begin{array}{l}0.861 \\
(0.143)\end{array}$ & $\begin{array}{l}0.982 * \\
(0.067)\end{array}$ \\
\hline D.logreer_cs & & $\begin{array}{l}0.196 \\
(0.710)\end{array}$ & $\begin{array}{l}-0.271 \\
(0.486)\end{array}$ & $\begin{array}{l}-0.090 \\
(0.773)\end{array}$ & $\begin{array}{l}-0.690 \\
(0.429)\end{array}$ & $\begin{array}{l}-0.983 \\
(0.212)\end{array}$ & $\begin{array}{l}0.793 \\
(0.284)\end{array}$ \\
\hline logreer & $\begin{array}{l}0.698 * * * \\
(0.000)\end{array}$ & & & & & & \\
\hline L.logfeer_cs & $\begin{array}{l}0.426 * * * \\
(0.000)\end{array}$ & & & & & & \\
\hline logreer_cs & $\begin{array}{l}-0.649^{* * *} \\
(0.000)\end{array}$ & & & & & & \\
\hline Constant & & $\begin{array}{l}0.072 \\
(0.687)\end{array}$ & $\begin{array}{l}0.359 \\
(0.136)\end{array}$ & $\begin{array}{l}0.167 \\
(0.482)\end{array}$ & $\begin{array}{l}0.583 * \\
(0.074)\end{array}$ & $\begin{array}{l}0.916 * * \\
(0.021)\end{array}$ & $\begin{array}{l}1.165 * * \\
(0.029)\end{array}$ \\
\hline CPMG & $\begin{array}{l}(1) \\
\text { D.logfeer }\end{array}$ & $\begin{array}{l}(14) \\
\text { IRL }\end{array}$ & $\begin{array}{l}\text { (15) } \\
\text { ITA }\end{array}$ & $\begin{array}{l}(16) \\
\text { JPN }\end{array}$ & $\begin{array}{l}(17) \\
\text { KOR }\end{array}$ & $\begin{array}{l}(18) \\
\text { MEX }\end{array}$ & $\begin{array}{l}\text { (19) } \\
\text { MYS }\end{array}$ \\
\hline$E C$ & & $\begin{array}{l}-0.436 * * * \\
(0.000)\end{array}$ & $\begin{array}{l}-0.321^{* *} \\
(0.013)\end{array}$ & $\begin{array}{l}-0.585 * * * \\
(0.000)\end{array}$ & $\begin{array}{l}-0.449 * * * \\
(0.001)\end{array}$ & $\begin{array}{l}-0.180 * \\
(0.065)\end{array}$ & $\begin{array}{l}-0.236 \\
(0.181)\end{array}$ \\
\hline D.logreer & & $\begin{array}{l}0.007 \\
(0.967)\end{array}$ & $\begin{array}{l}0.302 \\
(0.135)\end{array}$ & $\begin{array}{l}0.333 * * * \\
(0.006)\end{array}$ & $\begin{array}{l}0.236 * * \\
(0.020)\end{array}$ & $\begin{array}{l}0.468 * * * \\
(0.000)\end{array}$ & $\begin{array}{l}0.856 * * * \\
(0.000)\end{array}$ \\
\hline D.logfeer_cs & & $\begin{array}{l}0.316^{*} \\
(0.064)\end{array}$ & $\begin{array}{l}-0.134 \\
(0.580)\end{array}$ & $\begin{array}{l}-0.0957 \\
(0.593)\end{array}$ & $\begin{array}{l}0.485 * * \\
(0.037)\end{array}$ & $\begin{array}{l}0.948 * * \\
(0.047)\end{array}$ & $\begin{array}{l}0.090 \\
(0.700)\end{array}$ \\
\hline D.logreer_cs & & $\begin{array}{l}0.186 \\
(0.486)\end{array}$ & $\begin{array}{l}-0.011 \\
(0.972)\end{array}$ & $\begin{array}{l}0.148 \\
(0.535)\end{array}$ & $\begin{array}{l}-0.824 * * * \\
(0.005)\end{array}$ & $\begin{array}{l}-0.336 \\
(0.643)\end{array}$ & $\begin{array}{l}-0.298 \\
(0.360)\end{array}$ \\
\hline logreer & $\begin{array}{l}0.698 * * * \\
(0.000)\end{array}$ & & & & & & \\
\hline L.logfeer_cs & $\begin{array}{l}0.426 * * * \\
(0.000)\end{array}$ & & & & & & \\
\hline logreer_cs & $\begin{array}{l}-0.649 * * * \\
(0.000)\end{array}$ & & & & & & \\
\hline Constant & & $\begin{array}{l}1.031 * * * \\
(0.007)\end{array}$ & $\begin{array}{l}0.767 * * \\
(0.0290)\end{array}$ & $\begin{array}{l}1.427 * * * \\
(0.009)\end{array}$ & $\begin{array}{l}1.084 * * * \\
(0.008)\end{array}$ & $\begin{array}{l}0.451^{*} \\
(0.087)\end{array}$ & $\begin{array}{l}0.554 \\
(0.206)\end{array}$ \\
\hline
\end{tabular}


Table D.4: Short Run Dynamics (CPMG) (continued)

\begin{tabular}{|c|c|c|c|c|c|c|c|}
\hline CPMG & $\begin{array}{l}\text { (1) } \\
\text { D.logfeer }\end{array}$ & $\begin{array}{l}(20) \\
\text { NLD }\end{array}$ & $\begin{array}{l}(21) \\
\text { PHL }\end{array}$ & $\begin{array}{l}\text { (22) } \\
\text { PRT }\end{array}$ & $\begin{array}{l}\text { (23) } \\
\text { SPA }\end{array}$ & $\begin{array}{l}\text { (24) } \\
\text { THA }\end{array}$ & $\begin{array}{l}\text { (25) } \\
\text { UK }\end{array}$ \\
\hline$E C$ & & $\begin{array}{l}-0.308^{* * *} \\
(0.000)\end{array}$ & $\begin{array}{l}-0.176 \\
(0.178)\end{array}$ & $\begin{array}{r}-0.0943 \\
(0.220)\end{array}$ & $\begin{array}{l}-0.159 * * * \\
(0.000)\end{array}$ & $\begin{array}{l}-0.743^{* * *} \\
(0.000)\end{array}$ & $\begin{array}{l}-0.180^{*} \\
(0.066)\end{array}$ \\
\hline D.logreer & & $\begin{array}{l}0.500 * * * \\
(0.003)\end{array}$ & $\begin{array}{l}0.745 * * * \\
(0.004)\end{array}$ & $\begin{array}{l}2.488 * * * \\
(0.000)\end{array}$ & $\begin{array}{l}-0.880^{* * *} \\
(0.005)\end{array}$ & $\begin{array}{l}0.134 \\
(0.666)\end{array}$ & $\begin{array}{l}1.139 * * * \\
(0.000)\end{array}$ \\
\hline D.logfeer_cs & & $\begin{array}{l}0.493 * * * \\
(0.000)\end{array}$ & $\begin{array}{l}1.535 * * * \\
(0.004)\end{array}$ & $\begin{array}{l}01 / 01 / 23 \\
(0.138)\end{array}$ & $\begin{array}{l}1.244 * * * \\
(0.002)\end{array}$ & $\begin{array}{l}-0.113 \\
(0.845)\end{array}$ & $\begin{array}{l}0.098 \\
(0.611)\end{array}$ \\
\hline D. logreer_cs & & $\begin{array}{l}0.676 * * * \\
(0.000)\end{array}$ & $\begin{array}{l}-1.262 \\
(0.136)\end{array}$ & $\begin{array}{l}-1.651 * * \\
(0.043)\end{array}$ & $\begin{array}{l}-1.618 * * * \\
(0.002)\end{array}$ & $\begin{array}{l}-1.188 \\
(0.144)\end{array}$ & $\begin{array}{l}0.250 \\
(0.289)\end{array}$ \\
\hline logreer & $\begin{array}{l}0.698^{* * * *} \\
(0.000)\end{array}$ & & & & & & \\
\hline L.logfeer_cs & $\begin{array}{l}0.426 * * * \\
(0.000)\end{array}$ & & & & & & \\
\hline logreer_cs & $\begin{array}{l}-0.649 * * * \\
(0.000)\end{array}$ & & & & & & \\
\hline Constant & & $\begin{array}{l}0.732 * * * \\
(0.002)\end{array}$ & $\begin{array}{l}0.408 \\
(0.213)\end{array}$ & $\begin{array}{l}0.259 \\
(0.196)\end{array}$ & $\begin{array}{l}0.398 * * * \\
(0.008)\end{array}$ & $\begin{array}{l}1.792 * * * \\
(0.002)\end{array}$ & $\begin{array}{l}0.444 * \\
(0.088)\end{array}$ \\
\hline CPMG & & $\begin{array}{l}\text { (1) } \\
\text { D.logfeer }\end{array}$ & & $\begin{array}{l}(26) \\
\text { URU }\end{array}$ & & $\begin{array}{l}(27) \\
\text { USA }\end{array}$ & \\
\hline EC & & & & $\begin{array}{l}-0.433^{* *} \\
(0.011)\end{array}$ & & $\begin{array}{l}-0.0784 \\
(0.246)\end{array}$ & \\
\hline D. logreer & & & & $\begin{array}{l}0.812 * * * \\
(0.000)\end{array}$ & & $\begin{array}{l}0.622 * * * \\
(0.000)\end{array}$ & \\
\hline D.logfeer_cs & & & & $\begin{array}{l}2.266 * * * \\
(0.000)\end{array}$ & & $\begin{array}{l}0.830^{* * *} \\
(0.004)\end{array}$ & \\
\hline D.logreer_cs & & & & $\begin{array}{l}-2.811 * * * \\
(0.004)\end{array}$ & & $\begin{array}{l}-0.106 \\
(0.766)\end{array}$ & \\
\hline logreer & & $\begin{array}{l}0.698 * * * \\
(0.000)\end{array}$ & & & & & \\
\hline L.logfeer_cs & & $0.426 * * *$ & & & & & \\
\hline logreer_cs & & $\begin{array}{l}-0.649 * * * \\
(0.000)\end{array}$ & & & & & \\
\hline Constant & & & & $\begin{array}{l}1.087 * * \\
(0.038)\end{array}$ & & $\begin{array}{l}0.205 \\
(0.238)\end{array}$ & \\
\hline
\end{tabular}

Notes: $p$-values are given in parentheses. $\mathrm{D}$ is the difference estimator, $\mathrm{L}$ is the lag operator, $\mathrm{EC}$ corresponds to the error correction term and the country name stands for the heterogeneous dynamic part of the error correction model. Variables with the suffix "_cs" correspond to cross-sectional average of the variables.

vource: author's calculations. 